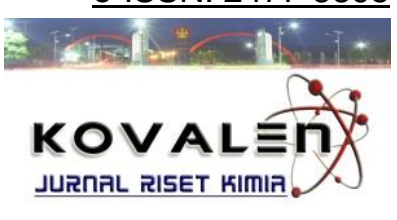

\title{
ANALISIS KANDUNGAN NUTRISI MIE KERING YANG DISUBTITUSIKAN AMPAS KELAPA
}

\author{
[Analysis of Nutrient Content of Dried Noodles Substituted Coconut Pulp]
}

\author{
Sylvia Florensy Bawias ${ }^{{ }^{\star}}$, Syamsuddin ${ }^{1}$, Prismawiryanti ${ }^{1}$, Ni Ketut Sumarni ${ }^{1}$ \\ 1) Jurusan Kimia, Fakultas MIPA, Universitas Tadulako, Palu \\ J. Soekarno Hatta Km.9, Kampus Bumi Tadulako Tondo Palu, Telp. 0451- 422611
}

*)Coresponding author: sylviabawias@yahoo.com

Diterima 24 April 2019, Disetujui 29 Oktober 2019

\begin{abstract}
Research has been carried out on the nutritional content of dried noodles substituted with coconut pulp. This study aims to determine the highest total protein content, highest crude fiber content and the highest water content and organoleptic quality of dried noodles substituted with coconut pulp. Dry noodles are made from wheat flour and coconut pulp as the main ingredients. The material ratio is varied to $90: 10 ; 80: 20 ; 70: 30$ and without the addition of coconut pulp flour. Dry noodles without the addition of coconut pulp flour produced the highest total protein content of $18.57 \%(\mathrm{~b} / \mathrm{b})$ and at the ratio of $70: 30$ the highest crude fiber was $17.55 \%(\mathrm{w} / \mathrm{w})$ and the highest water content was $2.63 \%$ $(w / w)$. Based on the quality of organoleptic dry noodles the most preferred is at the ratio of 90:10.
\end{abstract}

Keywords: Dry noodles, coconut pulp flour, total protein content, crude fiber content, water content, organoleptic quality.

\begin{abstract}
ABSTRAK
Telah dilakukan penelitian tentang kandungan nutrisi mie kering yang disubtitusikan dengan ampas kelapa. Penelitian ini bertujuan untuk mengetahui kadar protein total, kadar serat dan kadar air tertinggi serta mutu organoleptik mie kering yang disubtitusikan dengan ampas kelapa. Mie kering dibuat dari tepung terigu dan tepung ampas kelapa sebagai bahan utama. Rasio bahannya divariasikan menjadi 90:10; 80:20; 70:30 dan tanpa penambahan tepung ampas kelapa. Mie kering tanpa penambahan tepung ampas kelapa menghasilkan kadar protein total tertinggi sebesar $18,57 \%(\mathrm{~b} / \mathrm{b})$ serta pada rasio $70: 30$ menghasilkan serat kasar tertinggi sebesar $17,55 \%(\mathrm{~b} / \mathrm{b})$ dan kadar air tertinggi sebesar $2,63 \%(\mathrm{~b} / \mathrm{b})$. Berdasarkan mutu organoleptik mie kering yang paling banyak disukai yaitu pada rasio 90:10.
\end{abstract}

Kata Kunci: tepung ampas kelapa, mie kering, protein total, serat kasar, kadar air, mutu organoleptik. 


\section{LATAR BELAKANG}

Pertumbuhan penduduk semakin meningkat seiring berjalannya waktu sehingga kebutuhan makanan akan semakin meningkat baik secara kualitas maupun kuantitas (Ratnani, 2009). Salah satu produk makanan yang banyak diminati adalah mie. Di indonesia, mie telah menjadi pangan alternatif utama setelah nasi, hal ini menyebabkan tingkat ketergantungan terhadap tepung terigu sangat tinggi sehingga impor gandum terus meningkat (Biyumna et al., 2017). Mie merupakan produk makanan dengan bahan baku utama adalah tepung terigu, produk mie umumnya digunakan sebagai sumber energi karena memiliki karbohidrat yang tinggi. Akan tetapi, mie yang berbahan baku tepung terigu memiliki kadar serat yang kurang sehingga lambat dicerna dalam tubuh manusia (Billina et al., 2014).

Untuk memperoleh makanan yang memiliki nilai positif bagi kesehatan perlu dilakukan dengan cara pengolahan yang baik. Salah satu inovasi makanan yang dapat dikembangkan adalah mie kering. Mie kering merupakan produk makanan kering yang dibuat dari tepung terigu dengan penambahan bahan makanan lain dan bahan tambahan yang diizinkan, berbentuk khas mie (Biyumna et al., 2017). Saat ini telah banyak dilakukan inovasi untuk mengurangi penggunaan tepung terigu dengan cara mensubtitusi dengan berbagai sumber daya lokal yang dapat dibuat menjadi tepung dan digunakan sebagai bahan subtitusi tepung terigu. Biyumna et al. (2017) menggunakan tepung sukun sebagai subtitusi tepung terigu dengan penambahan telur dalam pembuatan mie kering. Rasio terbaik tepung terigu : tepung sukun : telur yang diperoleh pada penelitian ini yaitu 90:10:10, dengan kadar protein sebesar $11,7 \%$, kadar air 9,55\%, kadar abu 0,58\%, kadar lemak 1,12\%. Nasution (2005) telah menggunakan tepung rumput laut sebagai subtitusi tepung terigu yang difortifikasi dengan tepung kacang kedelai dalam pembuatan mie kering. Rasio terbaik tepung terigu : tepung rumput laut : tepung kacang kedelai yang diperoleh yaitu 60:20:20, dengan kadar protein yang didapatkan sebesar 39,60 \%, kadar air $3,44 \%$ dan kadar abu 1,6 \%. Ali dan Ayu (2009) menggunakan tepung pati ubi jalar di subtitusi dengan tepung terigu pada pembuatan mie kering. Rasio terbaik tepung terigu : tepung pati ubi jalar yang diperoleh yaitu 80:20 dengan kadar protein yang diperoleh sebesar $8,90 \%$, kadar air $7,31 \%$ dan kadar abu 0,78 \%. Selain itu, mie kering juga dapat diolah dengan cara memanfaatkan bahan yang tidak bermanfaat lagi namun memiliki kandungan serat dan protein yang tinggi, salah satunya ampas kelapa.

Ampas kelapa merupakan hasil samping dari olahan buah kelapa. Buah kelapa dapat diolah menjadi bermacammacam produk seperti minyak kelapa, santan, tepung kelapa, manisan, dan sebagainya. Masyarakat biasanya 
memanfaatkan ampas kelapa ini hanya sebagai pakan ternak karena dianggap merupakan hasil samping yang tidak bernilai (Meri et al., 2015). Meskipun ampas kelapa hanyalah hasil samping dari santan tapi kandungan gizi ampas kelapa masih cukup bernilai. Menurut Meri et al. (2015) tepung ampas kelapa yang dikeringkan dengan metode freeze drying selama 24 jam menghasilkan protein sebesar $4,12 \%$, lemak $12 \%$, dan serat kasar $37,1 \%$.

Kandungan gizi yang dimiliki oleh ampas kelapa menjadikan ampas kelapa sebagai salah satu pengganti tepung terigu dalam pengolahan berbagai produk pangan. Pada penelitian Setiawati et al. (2015) tepung ampas kelapa digunakan untuk pembuatan brownies kaya serat dengan substitusi tepung ampas kelapa $\leq$ $60 \%$ dan menghasilkan kadar serat kasar 8,87\%. Fitri et al. (2016) menggunakan tepung kelapa dan pati sagu untuk pembuatan kue bangkit dengan rasio terbaik antara tepung kelapa dan pati sagu $30: 70$ menghasilkan kadar protein $8,60 \%$. Pada penelitian Yusmarini dan Raswen (2013) tepung ampas kelapa dan tepung biji nangka digunakan sebagai substitusi tepung terigu dalam pembuatan mi basah. Rasio terbaik tepung terigu : tepung biji nangka : tepung ampas kelapa yang diperoleh pada penelitian ini yaitu 80:15:5, dengan kadar protein yang diperoleh sebesar $8,02 \%$.

Berdasarkan kandungan yang dimiliki ampas kelapa serta pemanfaatannya dalam bidang pangan maka penulis telah membuat inovasi pembuatan mie kering dalam hal ini bahan dasar pembuatan mie kering yang disubtitusi dengan tepung ampas kelapa sehingga dapat menghasilkan produk olahan yang memiliki protein, serat dan mutu organoleptik yang baik.

\section{METODOLOGI PENELITIAN}

\section{Bahan dan Peralatan}

Bahan yang digunakan pada penelitian ini yaitu ampas kelapa, tepung terigu, telur, garam, STPP (sodium tripolifosfat), air, $\mathrm{H}_{2} \mathrm{SO}_{4}$ pekat, $\mathrm{H}_{2} \mathrm{SO}_{4} 0,3$ $\mathrm{N}, \mathrm{NaOH} 30 \%, \mathrm{H}_{3} \mathrm{BO}_{3} 2 \%, \mathrm{HCl} 0,01 \mathrm{~N}$, $\mathrm{NaOH} 1,5 \mathrm{~N}$, aseton, aquades, kertas saring.

Peralatan yang digunakan pada penelitian ini yaitu oven, blender, ayakan 60 mesh, hotplate, stopwatch, corong Buchner, labu Kjeldahl, penangas listrik, lemari asam, labu destilasi, botol semprot, desikator, neraca analitik, penggiling mie, pisau, panci, kompor.

\section{Prosedur Kerja}

\section{Pembuatan Tepung Ampas Kelapa (Setiawati et al., 2015)}

Tahap pembuatan tepung ampas kelapa yaitu ampas kelapa hasil pemerasan santan sebanyak 7 kali dan dikeringkan menggunakan oven selama 2 jam pada suhu $105^{\circ} \mathrm{C}$. Selanjutnya dihancurkan menggunakan blender dan diayak dengan ayakan 60 mesh. 
Pembuatan Mie Kering (Biyumna et al., 2017)

Semua bahan dicampurkan secara merata selama \pm 3 menit dengan perbandingan seperti yang tertera dalam tabel. Kemudian adonan dicetak menggunakan alat penggiling mie ketika mie keluar, mie dipotong-potong menggunakan pisau dengan panjang \pm 7 $\mathrm{cm}$. Agar tidak lengket, potongan-potongan mie yang telah terbentuk ditaburi dengan sedikit tepung. Selanjutnya potonganpotongan mie dikukus selama 10-15 menit, kemudian diangkat dan diletakkan di atas loyang bersih. Selanjutnya dikeringkan menggunakan oven pada suhu $50^{\circ} \mathrm{C}$ selama \pm 18 jam. Prosedur yang sama juga dilakukan untuk pembuatan mie kering tanpa penambahan tepung ampas kelapa.

Tabel 1 Perbandingan bahan- bahan pembuatan mie kering

\begin{tabular}{cccc}
\hline Bahan & \multicolumn{3}{c}{ Berat bahan (gram) } \\
\cline { 2 - 4 } $\begin{array}{c}\text { pangan } \\
\text { (gram) }\end{array}$ & F1 & F2 & F3 \\
\hline Tepung ampas & 10 & 20 & 30 \\
kelapa & 90 & 80 & 70 \\
$\begin{array}{c}\text { Tepung terigu } \\
\text { Telur }\end{array}$ & 10 & 10 & 10 \\
$\begin{array}{c}\text { Garam } \\
\text { STPP }\end{array}$ & 2 & 2 & 2 \\
$\begin{array}{c}\text { (sodium } \\
\text { tripolifosfat) }\end{array}$ & 0,3 & 0,3 & 0,3 \\
Air & 35 & 35 & 35 \\
\hline
\end{tabular}

\section{Analisis Kadar Protein (AOAC, 2005)}

Menimbang sampel mie kering dari berbagai variasi komposisi sebanyak 0,5 gram lalu memasukkan ke dalam labu khjedhal, kemudian menambahkan 1,2 gr katalis campuran dan $10 \mathrm{~mL} \mathrm{H}_{2} \mathrm{SO}_{4}$ pekat. Labu khjedhal bersama isinya digoyangkan sampai semua sampel terbasahi dengan $\mathrm{H}_{2} \mathrm{SO}_{4}$ pekat. Selanjutnya mendekstruksi campuran di atas pemanas listrik dalam lemari asam sampai cairan hijau jernih terbentuk. Membiarkan dingin kemudian tuang ke dalam labu ukur $100 \mathrm{~mL}$ dan impitkan sampai tanda batas dengan aquades. Menyiapkan erlenmeyer (penampung) yang berisi $10 \mathrm{~mL} \mathrm{H}_{3} \mathrm{BO}_{3} 2 \%$ dan 4 tetes indikator campuran. Kemudian memipet $5 \mathrm{~mL}$ larutan dari labu ukur, masukkan ke dalam labu destilasi $100 \mathrm{~mL}$ dan menambahkan $5 \mathrm{~mL} \mathrm{NaOH} \mathrm{30 \%} \mathrm{dan}$ $100 \mathrm{~mL}$ air suling. Setelah memperoleh destilat sebanyak $\pm 50 \mathrm{~mL}$, destilasi dihentikan ( \pm 5 menit). Erlenmeyer (penampung) bersama isinya dititrasi dengan larutan $\mathrm{HCl} 0,01 \mathrm{~N}$ sampai terjadi perubahan warna (V1). Kemudian membuat uji blanko, $(\mathrm{V} 2=$ volume $\mathrm{HCl})$ yang dibutuhkan.

$$
\begin{aligned}
& \text { Kadar protein }(\%)=\frac{(\mathrm{V} 1-\mathrm{V} 2) \mathrm{N} \times 14 \times 6,25 \times \mathrm{P}}{\mathrm{mg} \mathrm{sampel}} \times 100 \% \\
& \begin{array}{l}
\text { Keterangan : } \\
\mathrm{V} 1=\text { Volume titrasi sampel } \\
\mathrm{V} 2=\text { Volume titrasi blanko } \\
\mathrm{N}=\text { Normalitas larutan } \mathrm{HCl} 0,01 \mathrm{~N} \\
\mathrm{P}=\text { Faktor pengenceran }
\end{array}
\end{aligned}
$$

\section{Analisis Kadar Serat (Fajri, 2015)}

Sampel ditimbang sebanyak 1 gram, kemudian dimasukkan ke dalam gelas kimia $250 \mathrm{~mL}$ dan ditambahkan $50 \mathrm{~mL}$ $\mathrm{H}_{2} \mathrm{SO}_{4} \quad 0,3 \mathrm{~N}$ lalu dipanaskan pada suhu $70^{\circ} \mathrm{C}$ selama 1 jam. Selanjutnya ditambahkan $25 \mathrm{ml} \mathrm{NaOH} \mathrm{1,5} \mathrm{N}$ dan dipanaskan selama 30 menit pada suhu $70^{\circ} \mathrm{C}$. Kemudian larutan disaring menggunakan corong buchner. Selama 
penyaringan endapan dicuci berturut-turut dengan aquades panas secukupnya, $50 \mathrm{ml}$ $\mathrm{H}_{2} \mathrm{SO}_{4}$ 0,3 N, dan $25 \mathrm{~mL}$ aseton. Kemudian kertas saring berisi residu dimasukkan ke dalam cawan petri dan keringkan di dalam oven selama 1 jam dengan suhu $105^{\circ} \mathrm{C}$. Kemudian didinginkan dan ditimbang.

Kadar serat kasar $(\%)=\frac{b-a}{X} \times 100 \%$

Keterangan :

$\mathrm{b}=$ bobot kertas saring + sampel setelah dioven

$\mathrm{a}=$ bobot kertas saring

$\mathrm{x}=$ bobot sampel

\section{Analisis Kadar Air (Djamil, 2015)}

Cawan petri dicuci, dikeringkan kemudian diberi label dan dipanaskan di dalam oven selama 30 menit pada suhu $110^{\circ} \mathrm{C}$. Cawan petri selanjutnya dimasukkan ke dalam desikator selama 30 menit. Sampel ditimbang sebanyak 1 gram, dipanaskan di dalam oven selama 2 jam pada suhu $105^{\circ} \mathrm{C}$, didinginkan didalam desikator dan ditimbang. Perlakuan diulangi sampai berat konstan.

$$
\text { Kadar air }(\%)=\frac{B A}{B S} \times 100 \%
$$

Keterangan:

$\mathrm{BA}=$ bobot akhir

$\mathrm{BS}=$ bobot sampel

Uji Organoleptik (Meilgaard et al., 2000 dalam Biyumna et al., 2017)

Uji organoleptik dilakukan untuk menguji aroma, rasa, tekstur, warna mie kering dan kesukaan secara keselurhan. Pengujian dilakukan dengan memberikan 4 sampel mie (3 mie perlakuan dan satu mie sebagai kontrol). Penelis tidak terlatih sebanyak 20 orang diminta memberikan penilaian kesan suka atau tidak suka terhadap karakteristik mutu mie kering yang disajikan dengan menuliskan tingkat kesukaan dengan skala numerik 1 (sangat tidak suka) sampai 5 (sangat suka).

\section{HASIL DAN PEMBAHASAN}

\section{Kadar Protein Total Mie Kering}

Hasil yang diperoleh dari analisis kadar protein total mie kering dengan variasi berat tepung terigu berbanding tepung ampas kelapa, F0 tanpa penambahan ampas kelapa; F1 (90:10); F2 (80:20); F3 (70:30) berturut-turut yaitu $18,57 \%, 18,38 \%, 18,33 \%$ dan $18,07 \%$ (Gambar 1).

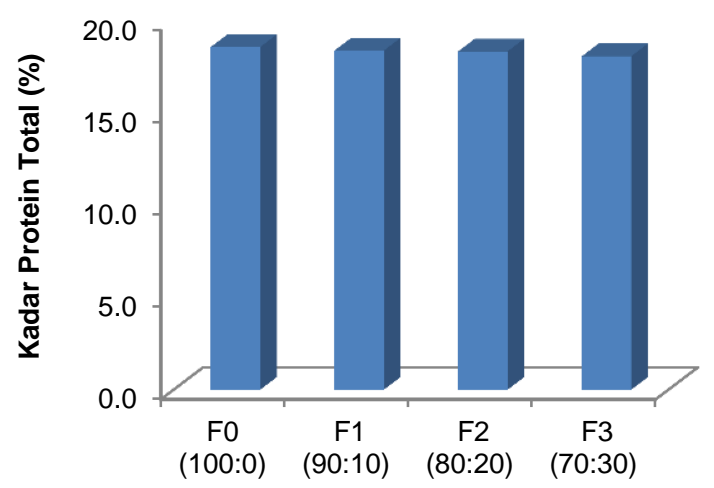

Rasio Tepung Terigu : Tepung Ampas Kelapa $(g / g)$

Gambar 1 Kadar protein total mie keringpada berbagai rasio terigu terhadap ampas kelapa

Hasil yang diperoleh menunjukkan semakin banyak penambahan tepung ampas kelapa maka kadar protein total yang dihasilkan semakin rendah, karena pada saat preparasi sampel dan pembuatan mie kering dilakukan proses pengeringan menggunakan suhu $105^{\circ} \mathrm{C}$ dan $50^{\circ} \mathrm{C}$. Menurut Astawan (2004), 
tepung terigu mengandung protein $12 \%$, sedangkan Putri (2010) melaporkan tepung ampas kelapa mengandung protein 5,78\%. Heryadi et al. (2013) dalam penelitiannya yang berjudul pengaruh penggunaan ubi jalar untuk subtitusi tepung terigu dan difortifikasi dengan tepung koro pedang menyatakan bahwa kadar protein yang dihasilkan berkisar 1317\%. Menurut Biyumna et al. (2017) dalam penelitiannya yang berjudul karakteristik mie kering terbuat dari tepung sukun dan penambahan telur menyatakan bahwa kadar protein mie kering tepung sukun berkisar 11,72-11,88\%. Menurut SNI 012974-1996 (BSN, 1996) standar mutu mie kering memiliki kadar protein minimal $11 \%$ atau seluruh perlakuan memenuhi standar minimal. Analisis sidik ragam dengan menghasilkan nilai signifikan 0,961 > $\alpha$ $(0,05)$, dengan kata lain variabel rasio bahan berpengaruh tidak nyata terhadap kadar protein total mie kering.

\section{Kadar Serat Mie Kering}

Hasil analisis kadar serat mie kering dengan variasi berat tepung terigu berbanding tepung ampas kelapa, F0 tanpa penambahan ampas kelapa; $\mathrm{F} 1$ (90:10); F2 (80:20); F3 (70:30) berturutturut yaitu 1,53\%, 14,02\%, 16,93\% dan $17,55 \%$ (Gambar 2).

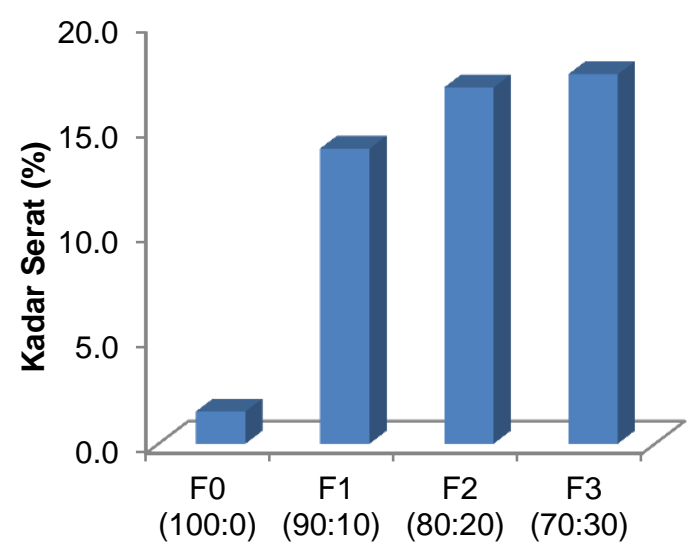

Rasio Tepung Terigu : Tepung Ampas Kelapa (g/g)

Gambar 2 Kadar serat mie kering pada berbagai rasio terigu terhadap ampas kelapa

Hasil yang diperoleh menunjukkan bahwa semakin banyak penggunaan tepung ampas kelapa maka kadar serat mie kering semakin tinggi hal ini disebabkan kandungan serat tepung kelapa jauh lebih tinggi daripada tepung terigu. Putri (2010) melaporkan bahwa tepung ampas kelapa mengandung serat sebesar $20 \%$. Tarigan et al. (2015) dalam penelitiannya menyatakan bahwa kadar serat pada tepung terigu hanya sebesar 0,4\%. Tarigan et al. (2015) dalam penelitiannya yang berjudul Pemanfaatan tepung kelapa dalam pembuatan mie kering menyatakan bahwa kadar serat mie kering dari tepung kelapa berkisar 11,3514,43\%. Nugrahawati (2011) dalam penelitiannya yang berjudul kajian karakteristik mie kering dengan subtitusi bekatul menyatakan bahwa kadar serat mie kering yang disubtitusi dengan bekatul beras putih sebesar $4,52 \%$ dan kadar serat mie kering yang disubtitusi dengan bekatul beras ketan sebesar $4,90 \%$. 
Pada tabel SPSS menggunakan metode ONEWAY ANOVA dengan variabel rasio menunjukkan nilai signifikan ialah 0,000<0,05 ( $\alpha$ ) sehingga dilanjutkan menggunakan uji lanjut Duncan. Hasil uji Duncan menunjukkan semua rasio berbeda nyata.

\section{Kadar Air Mie Kering}

Kadar air merupakan banyaknya air yang terkandung dalam suatu bahan yang dinyatakan dalam persen, apabila kadar air melebihi standar mutu maka akan berpengaruh terhadap produk yang dihasilkan dan semakin tinggi kadar air yang terkandung pada produk maka akan berpengaruh pada tekstur dan cita rasa produk (Winarno, 2004).

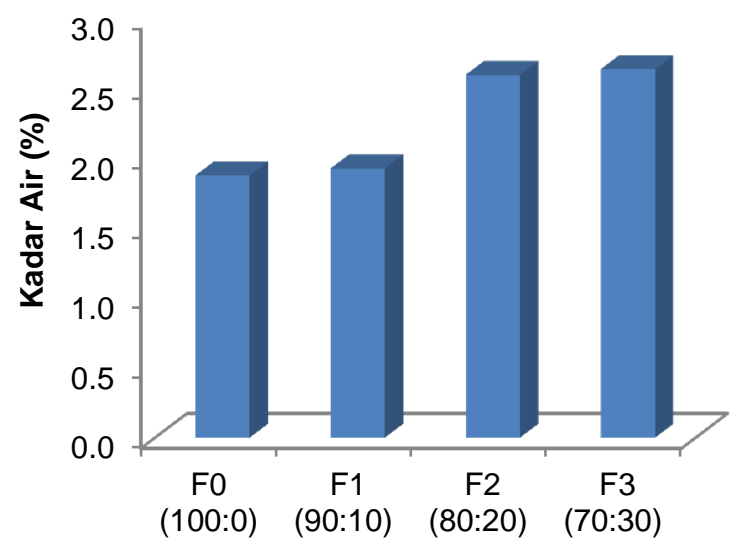

Rasio Tepung Terigu : Tepung Ampas Kelapa $(\mathbf{g} / \mathbf{g})$

Gambar 3 Kadar air mie kering pada berbagai rasio terigu terhadap ampas kelapa

Hasil yang diperoleh menunjukkan bahwa kadar air tertinggi diperoleh pada rasio 70:30 yaitu sebesar $2,63 \%$ sedangkan,kadar air terendah terdapat pada rasio tanpa penambahan tepung ampas kelapa yaitu sebesar 1,88\%. Semakin banyak penambahan tepung ampas kelapa maka kadar air yang dihasilakan semakin tinggi. $\mathrm{Hal}$ ini dikarenakan Menurut Mulyani (2013) dalam Rakhmawati et al. (2014) menyatakan serat memiliki kemampuan mengikat air, air yang terikat kuat dalam serat pangan sulit untuk diuapkan kembali walaupun dengan proses pengeringan. Menurut Winarno (2008), serat dapat menyerap air. Semakin sedikit kadar air maka tekstur dan cita rasa mie kering semakin bagus. Standar mutu mie kering sesuai SNI 01-2974-1996 yaitu memiliki kadar air maksimal $8 \%$, atau seluruh perlakuan memenuhi standar maksimal.

Pada tabel SPSS menggunakan metode ONEWAY ANOVA dengan variabel rasio menunjukkan nilai signifikan ialah $0,000<0,05(\alpha)$ sehingga perlu dilanjutkan menggunakan uji lanjut Duncan. Hasil uji Duncan menunjukkan semua rasio berbeda nyata.

\section{Mutu Organoleptik}

Mutu mie kering juga ditinjau dari mutu organoleptic yang dihasilkan. Mutu organoleptic digunakan untuk menilai aspek flavor dari mie kering, baik dari rasa, aroma, tekstur mauoun warna dengan menggunakan beberapa orang panelis (Setyaningsih, 2010). Respon penelis terhadap analisis sensori dalam pengujian organoleptik yang melibatkan 20 panelis.

\section{Aroma}

Rasio tepung terigu dan tepung ampas kelapa dapat mengubah tingkat kesukaan mie kering sehingga perlu 
dilakukan pengujian aroma mie kering untuk mengetahui mie kering yang aromanya lebih disukai. Aroma atau bau dapat dipakai juga sebagai suatu indikator terjadinya kerusakan pada produk (Sigit A et al., 2010). Cita rasa dan aroma timbul karena adanya senyawa kimia alamiah maupun sintetik dan reaksi senyawa tersebut dengan ujung-ujung syaraf indera lidah dan hidung (Winarno dan Koswara, 2002).

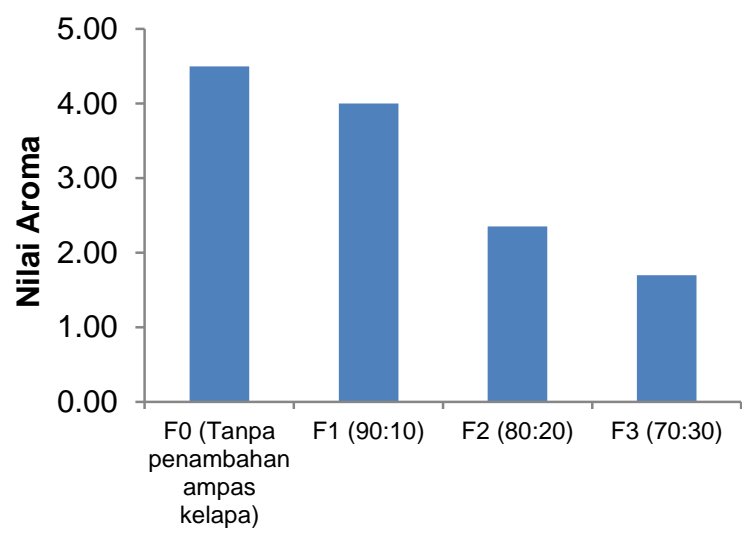

Rasio Tepung Terigu : Tepung Ampas Kelapa $(\mathbf{g} / \mathbf{g})$

Gambar 4 Grafik respon panelis terhadap aroma mie kering

Respon panelis terhadap aroma mie kering yang paling banyak dipilih yaitu pada rasio tanpa penambahan tepung ampas kelapa sebesar 4,50 dan paling sedikit yang memilih yaitu pada rasio tepung terigu dan tepung ampas kelapa 70:30 sebesar 1,70 (Gambar 4). Hal ini dikarenakan semakin banyak penambahan tepung ampas kelapa dapat menyebabkan aroma mie yang dihasilkan berbau tengik. maka dari itu peneliti menawarkan solusi agar aroma yang dihasilkan lebih baik perlu ditambahkan bahan lain yang dapat meminimalisir aroma ampas kelapa seperti pengunaan bawang putih. Menurut Putro (2008) bahan yang dapat menghilangkan aroma yang tidak enak pada makanan dan sebagai penyedap rasa adalah bawang putih. Selain itu, bawang putih juga dapat digunakan sebagai salah satu bahan yang dapat memberikan efek kesehatan seperti menghambat pertumbuhan bakteri patogen.

\section{Warna}

Warna olahan mie kering sangat menentukan penerimaan konsumen dan memberikan suatu petunjuk mengenai perubahan kimia dalam bahan pangan.

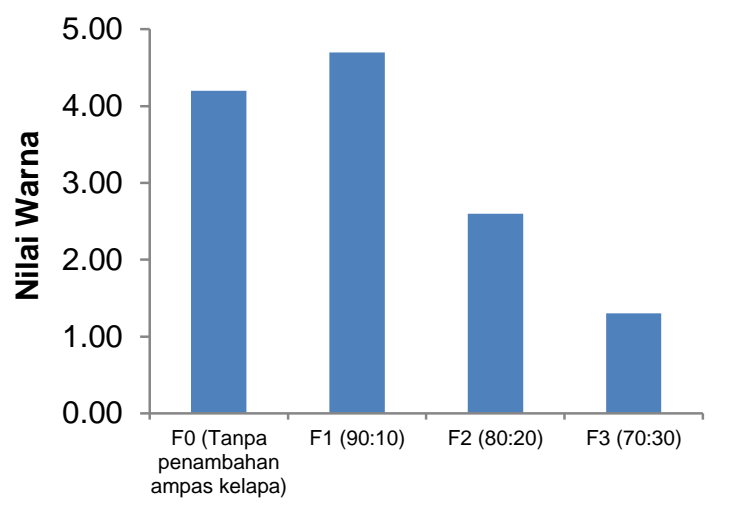

Rasio Tepung Terigu : Tepung Ampas Kelapa $(\mathbf{g} / \mathbf{g})$

Gambar 5 Grafik respon panelis terhadap warna mie kering

Respon panelis terhadap warna mie kering dapat dilihat pada grafik, yang paling banyak dipilih yaitu pada rasio 90:10 sebesar 4,70 dan paling sedikit yang memilih yaitu pada rasio 70:30 sebesar 1,30 (Gambar 5). Hal ini menunjukkan adanya perbedaan respon panelis terhadap warna mie kering dikarenakan meningkatnya jumlah tepung ampas kelapa yang digunakan, FO berwarna 
kuning, F1 berwarna kuning kecokelatan, F2 berwarna kecokelatan dan F3 berwarna pucat kecokelatan.

Menurut Sigit A (2010) warna merupakan suatu sifat bahan yang berasal dari penyebaran spectrum sinar. Warna menggambarkan sensasi sensori seseorang karena adanya rangsangan dari seberkas energi radiasi yang jatuh ke indra penglihatan. Bahan pangan atau olahannya dengan warna yang menarik dapat menimbulkan selera seseorang untuk mencoba produk tersebut karena warna merupakan salah satu profil visual yang menjadi kesan pertama konsumen dalam menilai suatu produk.

\section{Rasa}

Menurut Waysima dan Adawiyah (2010), uji organoleptik juga mencakup analisa karakteristik bahan pangan yang diterima oleh indera pencicipan.

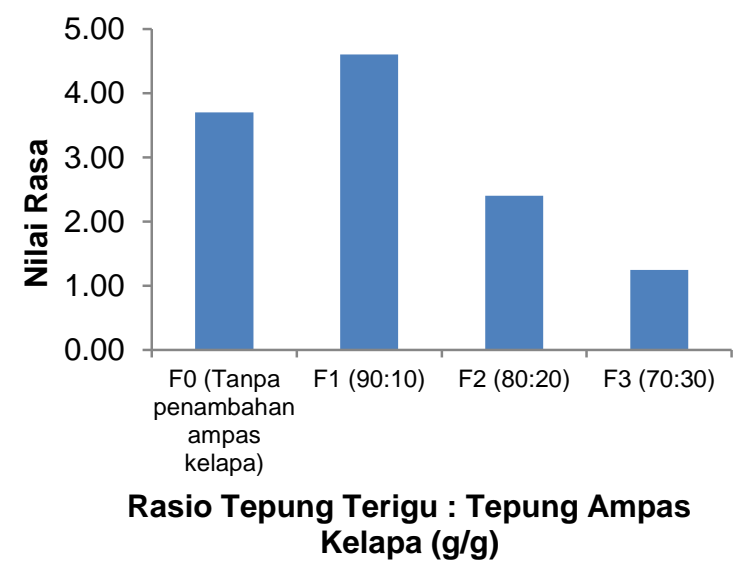

Gambar 6 Grafik respon panelis terhadap rasa mie kering

Rasa mie kering berkisar antara 3,70-1,25 dan diketahui bahwa mie kering dengan rasio 90:10 memiliki tingkat kesukaan yang paling tinggi dibandingkan dengan mie kering lainnya (Gambar 6).
Semakin banyak penambahan tepung ampas kelapa menyebabkan mie kering yang dihasikan memberikan rasa serat yang tertinggal di kerongkongan.

\section{Tekstur}

Tekstur merupakan salah satu faktor penting dalam penentuan mutu olahan mie kering. Perubahan tekstur olahan bahan pangan, seperti mie kering dapat mengubah rasa dan bau yang timbul karena akan mempengaruhi kecepatan timbulnya rangsangan terhadap sel reseptor olfaktori dan kelenjar air liur (Winarno, 2008).

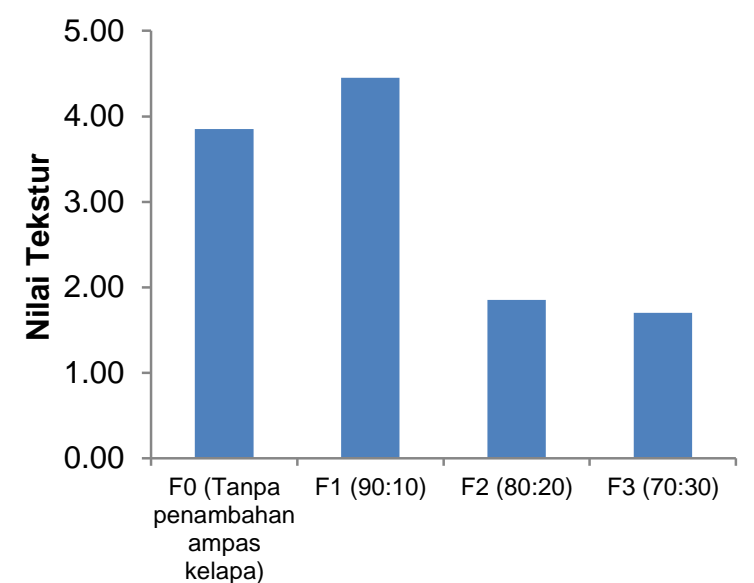

$$
\begin{gathered}
\text { Rasio Tepung Terigu : Tepung Ampas } \\
\text { Kelapa }(\mathbf{g} / \mathbf{g})
\end{gathered}
$$

Tekstur mie kering yang memiliki tingkat kesukaan paling tinggi berada pada rasio 90:10 (Gambar 7). Seiring dengan semakin banyaknya tepung ampas kelapa yang digunakan dalam pembuatan mie kering, tekstur yang dihasilkan semakin rapuh, hal ini dikarenakan berkurangnya jumlah gluten yang terkandung dalam adonan. Tidak adanya gluten pada tepung ampas kelapa membuat adonan tidak 
cukup untuk mengikat air yang ada sehingga adonan mie yang dihasilkan mempunyai tekstur rapuh dan mudah patah (Tarigan et al., 2015)

\section{KESIMPULAN}

Subtitusi tepung terigu dan tepung ampas kelapa dalam pembuatan mie kering yang menghasilkan kadar protein tertinggi terdapat pada rasio tanpa penambahan tepung ampas kelapa sebesar 18,57\%, kadar serat kasar tertinggi terdapat pada rasio 70:30 sebesar $17,55 \%$ dan kadar air tertinggi terdapat pada rasio $70: 30$ sebesar $2,63 \%$.

Mie kering tanpa penambahan tepung ampas kelapa memiliki aroma yang paling banyak disukai dan mie kering pada rasio 90:10 merupakan rasio yang paling banyak disukai dari segi rasa,warna dan tekstur.

\section{DAFTAR PUSTAKA}

Ali A., Ayu F.D. 2009. Subtitusi Tepung Terigu dengan Tepung Pati Ubi Jalar (Ipomea batatas L.) pada Pembuatan Mie Kering. Jurnal Sagu, 8(1): 1-4.

AOAC. 2005. Official Methods Of Analysis. Association Of Official Analytical Chemists. Editor : Horwitz, W and G. W. Latimer, Jr. Published by AOAC International. $18^{\text {th }}$ Edition. USA.

Sigit A, B., Atmaka, W., Aprilianti, T. 2010. Kajian Sifat Fisikokimia dan Sensori Tepung Ubi Jalar Ungu (Ipomea batas Blackie) dengan Variasi Proses Pengeringan. Prosiding Seminar Nasional. Seminar Nasional, 11 Maret 2017. Surakarta: Fakultas Pertanian UNS.
Astawan M. 2004. Membuat Mie dan Bihun. Jakarta: Penebar Swadaya.

Badan Standarisasi Nasional. 1996. Syarat Mutu Mie Kering (SNI 01-29741996). Jakarta: Badan Standarisasi Nasional.

Billina A., Wayulo S., Suhandy D. 2014. Kajian Sifat Fisik Mie Basah dengan Penambahan Rumput Laut. Jurnal Teknik Pertanian Lampung, 4 (2) : 109-116.

Biyumna L.U.,Windrati S.W., Diniyah N. 2017. Karakteristik Mie Kering Terbuat dari Tepung Sukun (Atrocorpus altilis) dan Penambahan Telur. Jurnal Agroteknologi, 11(1): 23 $-34$.

Djamil, L., Bahri, S., Nurhaeni. 2015. Analisis Retensi Antosianin dalam Proses Pembuatan dan Penyimpanan Bubur Instan dari Ubi Jalar Ungu (Ipomoea batatas). Natural Science, 4(3): 322-328.

Fajri, M.R. 2015. Analisis Kadar Protein Kasar Dan Serat Kasar Wafer Limbah Jerami Klobot Dan Daun Jagung Selama Masa Penyimpanan. Skripsi. Makassar: Fakultas Peternakan, Universitas Hasanuddin.

Fitri A, Raswen E, dan Yusmarini. 2016. Pemanfaatan Pati Sagu dan Tepung Kelapa dalam Pembuatan Kue Bangkit. Jom Faperta UR, 3(2).

Heryadi P., Windi A., Sri H., Achmad Ridwan A. 2013. Pengaruh Penggunaan Ubi Jalar Untuk Subtitusi Terigu Yang Difortifikasi Dengan Tepung Koro Pedang (Canavalia Ensiformis L. DC) Dalam Pembuatan Mie Kering. Jurnal Teknologi Hasil Pertanian, VI(2): 5967.

Meri Y., Widya E., Tarsono., M.Alfian R. 2015. Pemanfaatan Ampas Kelapa 
Sebagai Bahan Baku Tepung Kelapa Tinggi Serat Dengan Metode Freeze Drying. Jurnal integrasi proses, 5(2): $101-107$.

Nasution, Z.E. 2005. Pembuatan Mie Kering Dari Tepung Terigu dengan Tepung Rumput Laut yang Difortifikasi dengan Kacang Kedelai. Jurnal Sains Kimia, 9(2): 87-91.

Nugrahawati. 2011. Kajian Karakteristik Mie Kering Dengan Subtitusi Bekatul. Skripsi. Surakarta: Fakultas Pertanian, Universitas Sebelas Maret.

Putri, M. F. 2010. Tepung Ampas Kelapa pada Umur Panen 11-12 Bulan Sebagai Bahan Pangan Sumber Kesehatan. Jurnal Kompetensi Teknik, 8(2).

Putro. 2008. Aplikasi Ekstrak Bawang Putih untuk Memperpanjang Daya Simpan Ikan Kembung Segar (Rastelliger kamagurta). Jurnal Pascapanen dan Bioteknologi kelautan dan Perikanan, 3(2).

Ratnani, R.D. 2009. Bahaya Bahan Tambahan Makanan bagi Kesehatan. Jurnal IImiah Momentum, 5(1): $16-22$..

Setiawati, A.Rahimsyah, dan Ulyarti. 2015. Kajian Pembuatan Brownies Kaya Serat dari Tepung Ampas Kelapa. Jurnal Penelitian Universtas Jambi Seri Sains, 17:84-89.

Setyaningsih D. 2010. Analisis Sensori Untuk Industri Pangan dan Agro. Bogor: IPB.

Tarigan Yohannes T., Raswen E., Yusmarini. 2015. Pemanfaatan Tepung Kelapa Dalam Pembuatan Mie Kering. Jom Faperta, 2(2).

Tenda, T. 2004. Eksplorasi Aren (Arenga pinnata Merr) di Tomohon, Sulawesi Utara. Buletin Palma, 37:114-118.
Waysima dan Adawiyah, D.R. 2010. Evaluasi Sensori. Bogor: Institut Pertanian Bogor.

Winarno, F. G. dan S. Koswara. 2002. Telur: Komposisi, Penanganan dan Pengolahannya. Bogor: M-Brio Press.

Winarno, F G. 2004. Kimia Pangan dan Gizi. Jakarta: Gramedia Pustaka Utama.

Winarno F G. 2008. Kimia Pangan dan Gizi. Bogor: M-Brio Press.

Yusmarini dan Raswen E. 2013. Studi Pemanfaatan Tepung Biji Nangka dan Tepung Ampas Kelapa sebagai Substitusi Tepung Terigu dalam Pembuatan Mi Basah. Prosiding Seminar Nasional. Seminar Nasional "Peranan Teknologi dan Kelembagaan Pertanian dalam Mewujudkan Pembangunan Pertanian yang Tangguh dan Berkelanjutan", November 2013. Riau: Fakultas Pertanian, Universitas Riau. HIm. 335-344. 